\title{
A CONTRIBUTION TO THE KNOWLEDGE OF THE FISHES OF KANSAS.
}

By O. P. HAY.

The fishes enumerated in the following paper were collected during the month of July, 1885, by the writer and Prof. M. J. Thompson, of Bethany College, Weșt Virginia, while on a trip which extended from Concordia, Cloud County, Kansas, westward along the Missouri Pacific Railroad to Lenora, Norton County ; thence south across the country to Wa Keeney, in Trego County, on the Union Pacific Railroad; and from there to Wallace, Wallace County, near the western border of the State. Collections were made at Concordia; Beloit, Mitchell County; Kirwin, Phillips County; Lenora; in the Saline River, about 5 miles north of Wa Keeney; and in the Smoky Hill River at Wallace. Only 29 species of fishes were secured as the result of several days' hard work at dragging the seine. Of these, 2 are described as species prob. ably hitherto unnamed. The types of these supposed new species and specimens of most of the others have been sent to the National Museum.

\section{I.-Republican River at Concordia.}

On account of an accident, I am able to name but five species from this locality.

1. Hyodon alosoides (Raf.) J. \& G.

This species appears to be quite abundant in the Republican, as several specimens were observed which had been taken by fishermen with hooks.

2. Notropis lutrensis (Bd. \& Gd.) Gilbert.

3. Ictiobus velifer (Raf.) Jor. \& Meek.

One specimen, nearly 8 inches long, displays the following characters :

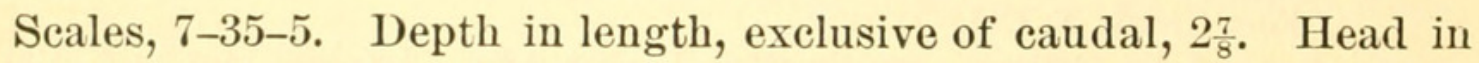
length, 4. Eye in head, 33. Operculum strongly striated. Dorsal rays, I, 24, the first soft ray three-fourths the length of the base of the dorsal. Snout blunt, about the diameter of the orbit, and overpassing a little the mouth.

4. Ictalurus punctatus (Raf.) Jor.

5. Amiurus melas (Raf.) Jor. \& Copel.

\section{II.-Solomon River at Beloit, Mitchell County.}

The collection was made not in the river itself, but in a small tributary stream just west of the town. This stream, like all others in this part of the State, flows in a deep ravine, is very sluggish, and so filled 
with ooze as to make the dragging of a seine a very difficult and disa. greeable task.

1. Boleosoma olmstedi (Stor.) Ag:

Two specimens secured; one with dorsal rays $\mathrm{X}, 13$, the other IX, 12.

2. Lepomis humilis (Grd.) Cope.

Many specimens of this brilliantly colored fish were obtained here, as at most other places visited. Two styles of coloration have been described; the one abounding in green and red, with orange spots, the other with plainer colors and spots of olive-brown. I have no doubt that the more gaudily ornamented individuals are males, and the plainer ones females. The males obtained at Beloit have the belly, breast, and lower fins orange-red and the sides of the body with orange spots, which in life were probably scarlet. The females, often swollen with spawn, are darker in general color and have on the sides spots of olive-green or brown. Probably young males resemble the females.

3. Lepomis cyanellus Raf.

Two specimens.

4. Semotilus atromaculatus Mitchill.

Semotilus corporalis Jordan \& Gilbert, Synop. Fishes N. A., 1882, 221.

A single specimen.

5. Phenacobius mirabilis (Grd.) Jor.

One specimen. Snout much longer than the diameter of the eye, which is contained in the length of the head $4 \frac{1}{2}$ times. Head in length, $4 \frac{1}{3}$. Teeth 4-4; scales 45. Recalls Cope's Sarcidium scopiferum.

6. Notropis megalops (Raf.) Jor. \& M'k.

Minnilus cornutus, Jordan \& Gilbert, Synopsis, 186.

7. Notropis lutrenis (Baird \& Girard) Gilbert.

Leuciscus lutrensis, Baird \& Girard, Proc. Acad. Nat. Sci., Phila., 1853, 391.

Leuciscus bubalinus, Baird \& Girard, loc. cit., 391.

Moniana gibbosa, Girard, Proc. Acad., Phila., 1856, 201.

Moniana lepida, Girard, Loc. cit., 197.

Cyprinella umbrosa, Girard, loc. cit., 197.

Cyprinella billingsiana?, Cope, Hayden's Annual Rep. G. \& G. Survey, 1870, 439.

Cyprinella forbesi, Jordan, Bulletin Ills. State Lab. Nat. Hist., 1878, 57.

This species, at once the commonest and the most beautiful minnow of the region west of the Mississippi, has suffered much at the hands of describers. This is due, in a great measure, to its great variability in form, dentition, colors, and probably scale-formula. With the possible exception of Professor Cope's Cyprinella billingsiana, all the nominal species cited above, together with others which Professors Jordan and Gilbert have already shown to be not valid, and possibly others of Girard's Cyprinelle, such as gunnisoni and suavis, that have not been identified by later students, must be included under the specific name lutrensis, given by Baird and Girard in 1853. The genera Moniana and Cyprinella were established on supposed differences in the dentition of the species arranged under each. It is now evident, however, that these 
differences are not even specific, but are rather individual variations, due possibly to age, sex, or accident. There is a good deal of difference between the two sexes in the colors; the females being usually quite plain and having yellow or orange fins; while the males are brilliant with blue and green reflections, and are especially marked by a shoulder band of violet. Their fins are bright red or orange. Professor Jordan (Proc. U. S. Nat. Mus., 1885, 9) has already recognized these differences in the sexes. Now, of these undoubted males, nearly all specimens examined have the teeth in a single row of 4 on each pharyngeal. In the collection made in the Saline, near Wa Keeney, is a specimen which yet, after lying in alcohol a year, retains some traces of the violet shoulder band and the orange of the snout and of the lower and caudal fins. Its dentition is plainly $1,4-4,1$. It is possible, howerer, that it is a female; but it is undistinguishable, except by its somewhat faded colors and dentition, from another specimen from the same place whose teeth are 4-4. In the Kirwin collection is an undoubted male, with the shoulder band bright violet, whose right pharyngeal has the outer row of four teeth and no trace of the inner-tooth, while the left pbaryngeal has the teeth 1-4. A female also is found in the same collection whose teeth are $1,4-4,0$; but there are some evidences that the inner tooth on the right side has been broken off. This latter specimen shows the following additional characters: Depth $2 \frac{1}{3}$ in length, scales 6-35-3; fins jellow, probably orange in life; anal filled with satiny pigment.

Many of the females obtained at Beloit have teeth 4-4; others 1, $4-4,0$; others still $1,4-4,1$. When the teeth are not symmetrically arranged on the two sides it is possible in some cases that a tooth may have been recently shed or broken off, but close examination usually shows no traces of its former existence.

It seems probable, therefore, that the young and many of the females have an inner tooth on one or both pharyngeals; while the adult males are seldom so provided.

The species varies much in the relation of depth to length of body. It is not difficult to obtain a series in which the ratio of depth to length rises gradually from $2 \frac{1}{2}$ to 4 , and this in specimens haring the same ab. solute length. If the deeper-bodied specimens should have the teeth in two rows, they might be regarded as belonging to Cyprinella umbrosa or bubalina; and the slenderer ones to suavis or lepida.

I think it will also be found that the number of scales in the lateral line is quite variable; but on this point I can speak with less confidence. C. umbrosa is stated to have 42 scales in the lateral line; but I am not aware that there is any other basis for this statement than Girard's figure.

8. Notropis macrostoma (Girard) Jor.

Cyprinella macrostoma, Girard, Proc. Acad., Phila., 1856, 198.

A single specimen found in the Beloit collection, and four in that made at Wa Keeney, are referred to the above species. At first view 
these have a striking resemblance to Notropis topeka Gilbert, but a close examination reveals several important differences. The teeth are 1,4-4. 1; the head much deeper than in N. topeka; the snout, viewed from the side, not nearly so pointed, and the anal rays, 9. Head in length to caudal, $4 \frac{1}{2}$; its depth at the oceiput nearly equal to its length; mouth moderate, the maxillary reaching to a perpendicular from the front of the orbit; the gape quite oblique; snout shorter than the eye, which is contained in the length of the head 3 times; teeth 1.4-4. 1, with hook and triturating surface, whose bounding edges are distinctly serrated; depth in length, 4 ; the body considerably compressed; dorsal, 8 ; anal, 9 ; the dorsal being inserted just behind the ventrals; scales in the decurved lateral line, 36 ; high, narrow, and closely imbricated; coloration much like that of $N$. toperia; scales above dark-edged; a dusky band along the sides, most conspicuous on the caudal peduncle, not terminating in a well-defined spot; a dusky dorsal streak; dorsal and caudal fins somewhat dusky, the others pale; top of the head and snout sprinkled with black dots.

In case future investigations should prove that these specimens are not to be referred to Girard's species, I propose for them the name of N. umbrifer.

\section{Notropis æneolus Hay, sp. nov.}

Body compressed and considerably elevated, the profile ascending from the snout to the dorsal fin. Head broad, the interorbital space in the length of the head, 21 times; diameter through the opercles in the length of the head, $1 \frac{3}{4}$. Snout blunt. Mouth small, terminal, and oblique; the lower jaw included within the upper in the closed mouth, the maxillary not attaining a perpendicular from the front of the eye. Eye small, eq tal to the snout, and its diameter in the length of the head 4 times. Head in length, $4 \frac{1}{8}$; depth, $3 \frac{1}{2}$. Scales, $6-35-5$, in very regular rows, not markedly higher than long, and rather loosely imbricated. Lateral line complete and little decurved. Caudal peduncle high and compressed, its median depth equal to one-half of the greatest depth of the body. Dorsal I, 8; A, I, 7. Dorsal directly over the insertion of the rentrals, high and falcate; its greatest height one-fifth of the length of the body; its base one-seventh the same unit; the pectorals scarcely reaching the base of the ventrals; these fully attaining the anterior ray of the anal. Anal high and falcate; its height 6 , and its base 9 times in the length of the body. Caudal deeply forked. Teeth 4-4, hooked, and with an evident grinding surface and slightly serrated edges. Color above brassy, with a tinge of green; below, orange. All the scales above the lateral line edged with dark points, which, becoming more abundant above, produce a dorsal streak. Along the lateral line there is a more or less conspicuous greenish band, and in most specimens each pore of the lateral line is conspicuously marked by dots. Top of the head orange and dusky, as well as the snout. All the rest 
of the head orange; belly also orange, as well as the fins. Pectorals dusky in front.

Of the species above described seven specimens were collected at Beloit, but the same species was obtained at Kirwin, Wa Keeney, and Wallace, which fact shows that it has a wide distribution and is quite abundant. A specimen from Wa Keeney, which has a total length of $3 \frac{1}{8}$ inches, is regarded as the special type of the species. The specimens from Kirwin and Wallace are the most brilliantly colored, the head, eyes, belly, and fins being of an intense orange hue.

It is possible that this is Girard's Moniana aurata, but the scales are not high and narrow enough to bring the species under Girard's genus Moniana. Professor Jordan also indicates that aurata closely resembles lutrensis, while it appears to me that my species is quite different.

10. Notropis deliciosus (Grd.) Jor. \& M'k.

A single specimen of a fish closely resembling an Indiana stramineus is referred to the above species. There appear to be 38 rows of scales crossing the lateral line.

11. Notropis topeka Gilbert.

Cliola topeka, Gilbert, Bull. Washburn Coll. Lab. i, 13.

Notropis topeka, Gilbert, loc. cit., i, 98.

Four specimens of a Notropis are referred to the above species. They, however, present some characters deviating somewhat from those assigned by Dr. Gilbert in his descriptions. The scales are 6-37-4. Eye larger than in the types, being greater than the snout and contained in the head 3 times. The rays of the dorsal, the caudal, and, to a less extent, of the anal, fins are ornamented with lines of black dots, giving the fins a dusky appearance.

In other respects these specimens conform to the original description.

12. Pimephales notatus (Raf.) Blatchley.

Hyborhynchus notatus, Jordan \& Gilbert, Synopsis, 159.

Pimephales notatus, Blatchley, W. S., Proc. Acad., Phila., 1885, 63.

Numerous specimens were collected which are referred to this species. Some of them are undistinguishable from specimens obtained in Indiana, except that at the caudal base there is a more sharply defined black spot. The scales are dark-edged above, and there is a plumbeous lateral band from the snout to the caudal spot, in some cases very distinct, in others obscure. The fins are of a creamy tint, varied with dusky. There is a spot on the anterior rays of the dorsal and indications of a band extending from this spot across the other rays.

The resemblance of this species to Cliola vigilax has often been remarked. My specimens agree quite well with Professor Jordan's description of this species in the Proc. U. S. National Museum, 1885, p. 3, except that the mouth is a little more inferior than it is in $C$. vigilax. 
It is possible that specimens of this latter species are included with $P$. notatus, but, if so, I am unable to distinguish them.

After a careful comparison of specimens of $P$. notatus from various quarters with the types of Hybopsis taurocephalus Hay (C. vigilax), found in Eastern Mississippi, I am unable to distinguish any generic differences between them; and even the specific differences are slight, but, doubtless, sufficient. There are no special differences in the dentition, the teeth of Pimephales being also more or less hooked. The alimentary canal of $P$. notatus varies much in length, sometimes being even less than twice the length of the body. The specimens from Kansas have the intestines about twice the length of the body, sometimes a little more, sometimes less. The structure of the dorsal spine in C. vigilax is the same as it is in Pimephales. It appears, therefore, probable that to the genus Pimephales must be assigned th ree species, promelas, notatus, and vigilax, and these three are closely related.

13. Pimephales promelas confertus (Grd.) Gilbert.

Abundant.

14. Campostoma anomalum (Raf.) Ag.

Two specimens.

15. Moxostoma macrolepidotum (LeS.) Jor.

Two specimens; one 10 inches long, fins bright orange, and considerable portions of the body charged with yellow pigment.

16. Catostomus teres (Mitchill) Günth.

17. Ictiobus velifer (Raf.) Jor. \& Meek.

18. Ictalurus punctatus (Raf.) Jor.

19. Amiurus melas (Raf.) Jor. \& Copel.

20. Lepidosteus osseus (L.) Ag.

One specimen $3 \frac{1}{2}$ inches long whose head formed one-third the total. length.

\section{III.-North Fork of Solomon River, at Kirwin, Phillips}

\section{County.}

The collection obtained at this point was made in a muddy, oozy, stream within a mile from the town. Only nine species were secured as the fruits of a day's hard work.

1. Lepomis humilis (Grd.) Cope.

2. Semotilus atromaculatus Mitchill.

3. Notropis megalops (Raf.) Jor. \& Meek.

4. Notropis deliciosus (Grd.) Jor. \& Meek.

Common, and much resembling specimens of same species trom Indiana. Scales of lateral line,38. Paler in color than specimens collected at most other points in Kansas. 
5. Notropis lutrensis (Bd. \& Gd.) Gilbert.

Abundant. Some females with teeth 1, 4-4, 1.

6. N. æneolus Hay.

Two specimens.

7. Pimephales promelas confertus (Grd.) Gilbert.

8. P. notatus (Raf.) Blateh.

9. Amiurus melās (Raf.) Jor. \& Copel.

One specimen.

IV.-Collection at Lenora, Norton County, North Fork of SOLOMON RIVER.

At Lenora the North Fork of the Solomon River is a small, and in most places a shallow, stream, flowing with sufficient rapidity to carry away the finer materials and leave for itself a clean bed of sand. $\Lambda$ part of our work was done in the main stream, but another part in a shallow, but in places, broad stream a mile from the village.

1. Etheostoma lepidum Baird \& Girard.

Boleosoma lepida, Baird \& Girard, Proc. Acad. Phila., 1853, 388.

Pocilichthys lepidus, Jordan \& Gilbert, Synopsis, 1882, 51\%.

To the above species I refer numerous specimens secured at Lenora. Since they, however, differ in some respects from any published descriptions of P. lepidus and of Aplesion pottsii, Oligocephalus grahami, $O$. leonensis, and $O$. pulchellus, all of which are regarded by Messrs. Jordan - \& Gilbert as identical, I proceed to give a somewhat detailed account of the specimens in my possession.

Body fusiform, somewhat compressed. Head pointed, contained in the length to the caudal 4 times. Mouth little oblique, rather large, the maxillary extending back a little beyond the rertical from the anterior edge of the orbit. Jaws equal. Premaxillaries non-projectile. Teeth prominent. Eye moderate, equal to the snout, and 4 in the head. Operculum, cheeks, and breast scaleless. Outer lamina of the preopercular crenulated. Fins as follows: D X-13; A II. 7. Base of anterior dorsal in length of head and body $3 \frac{3}{4}$; its height one-half its length. Base of the soft dorsal in length to the caudal $4 \frac{2}{3}$; three-fourths as high as long. Anal base half that of the first dorsal. First anal spine strong.

Scales 6-50 to 53-3. Pores of the lateral line on 35 scales; these ceasing just behind the middle of the soft dorsal.

The ground color is a dark olive. There are in the males about 10 vertical bars of indigo blue, the posterior five of which are much the most distinct. These vertical bars are in many specimeus separated by bars of orange. Dorsals barred with indigo and orange. A dark 
bar below the eye and a sploteh on the opercle. Pectorals and anal indigo blue.

Many specimens, probably females, are less brilliant. In these the dark bars are more distinct anteriorly; being, rather, square blotches. Many of the scales above the lateral line have on them black spots which are arranged with some regularity in longitudinal rows. Belly and lower fins pale.

The rays of the dorsal fius vary from IX-12 to X-14; those of the anal may be II, 6 , but are usually II, 7 . One male has a length of $2 \frac{1}{2}$ inches.

2. Boleosoma olmstedi (Stor.) Ag.

Common. In some cases D. VIII-14, A. I, 11. One specimen has the fins, D. IX-12, A. I, 9, with breast sparsely scaled.

3. Lepomis cyanellus Raf.

Common.

4. Fundulus zebrinus Jor. \& Gilb.

Abundant in the shallow tributary. It is probably a fish that re. quires a clear stream.

5. Squalius elongatus (Kirt.) Jor. \& Gilb.

A single specimen.

6. Semotilus atromaculatus Mitchill.

Quite common. One specimen nearly 5 inches long with 65 scales along the lateral line; no visible barbel.

7. Phenacobius mirabilis (Grd.) Jor.

Several specimens were secured. Head in length $4 \frac{1}{2} ;$ D. $5 \frac{1}{3}$. Scales about 45 . Teeth $4-4$; no traces of an inner series.

9. Notropis megalops (Raf.) J. \& M.

10. Notropis umbratilis (Gd.) J. \& M.

Minnilus umbratilis, Jordan \& Gilbert, Synopsis, 200.

Four specimens secured.

11. Notropis deliciosus (Gd.) J. \& M.

12. Notropis lutrensis (Bd. \& Gd.) J. \& G.

Abundant and showing the same variations in the dentition as have been already referred to.

13. Pimephales promelas confertus (Grd.) Gilbert.

14. P. notatus (Raf.) Blatchley.

One specimen with the intestines barely twice as long as the body. Closely resembles an Fndiana specimen of the same species except that the caudal spot is a little more distinct. Might easily be taken for $P$. vigilax.

15. Chrosomus erythrogaster $\mathrm{Ag}$.

Two specimens. 
16. Campostoma anomalum (Raf.) Ag.

One of the commonest of fishes.

17. Catostomus teres (Mitch.) Günther.

18. Noturus flavus Raf.

One specimen only.

\section{V.-Saline River, near Wa Keeney, Trego County.}

The Saline at this point, 5 or 6 miles north of Wa Keeney, is a shallow, rather rapid prairie brook, with a clean, sandy bed. Its depth, when visited, raried from a few inches to 3 or 4 feet. Twenty-two species were secured.

1. Etheostoma lepidum (Bd. \& Gd.).

Numerous specimens of this brilliant little fish were secured. The Etheostomina appear to be meager in species in this region.

2. Boleosoma olmstedi (Stor.) Ag.

3. Lepomis humilis (Grd.) Cope.

4. Lepomis cyanellus Raf.

Several fine specimens were secured.

5. Fundulus zebrinus J. \& G.

Very abundant.

6. Hyodon alosoides (Raf.) J. \& G.

One small specimen.

7. Semotilus atromaculatus Mitchill.

8. Hybopsis biguttatus (Kirt.) J. \& M.

Numerous large specimens are found in the collection.

9. Hybopsis storerianus (Kirt.) J. \& M.

Hybopsis storerianus, Jordan \& Meek, Proc. U. S. Nat. Mus., 1885, 6.

In the Saline collection are several specimens that appear to belong to the above-named species. They are, however, in poor condition, the scales being so completely removed that their number cannot be determined. Moreover, the dentition differs from that heretofore assigned to this species, being neither 4-4 nor $1,4-4,0$, but $1,4-4,1$. Head in the length, $4 \frac{2}{3}$; depth, 5 . Otherwise the specimens conform to the descriptions.

10. Phenacobins mirabilis (Grd.) Jor.

11. Notropis megalops (Raf.) J. \& M.

Several small specimens and one with a total length of $5 \frac{1}{4}$ inches. This has the sides charged with rosy pigment. Branchiostegal region red. Lower fins orange.

12. Notropis deliciosus (Grd.) Jor. \& M'k.

13. Notropis lutrensis (Bd. \& Gd.) J. \& G.

Common, as it is elsewhere in Western Kansas. One male with its characteristic bright colors has the teeth 1, 4-4, 1 . 
14. Notropis æneolus Hay.

Four specimens of this species were collected in the Saline, of which one $3 \frac{1}{8}$ inches long is made the type of the species.

15. Pimephales promelas confertus (Grd.) Gilbert.

16. Pimephales notatus (Raf.) Blatchley.

17. Hybognathus nuchalis Ag.

A number of good specimens of this widely-distributed species were obtained. One of these has a total length of $4 \frac{1}{2}$ inches. These specimens appear to be somewhat more elongated than usual, the head and the greatest depth being each contained in the length to the caudal base 5 times. Eye small, its diameter in the length of the head $4 \frac{3}{4}$, and less than the snout. Scales 6-40-5. D. I, 8. A. I, 8. The dorsal is apparently more anterior than in specimens so far described, a perpendicular from the insertion of the ventrals leaving two-thirds of the dorsal base in front of it. Vertebral streak indistinct. One specimen has on the right pharyugeal 8 teeth, all of the same size. Four of these occupy the usual position; 3 form an inner row; while the remaining tooth stands outside of, but close against, the row of four teeth. On the left pharyngeal there are 6 teeth, the usual row of 4, then at each end of this row, but placed somewhat further out, another tooth. A hole in the bone midway between these two supernumerary teeth indicates that a seventh tooth has recently dropped or been broken off. Such an abnormal increase in the number of pharyngeal teeth has now and then been observed in other species, and it appears to occur in both pharyngeals at the same time. It is not at all unlikely that the genus Tirodon (Hay, Bull. U. S. Fish Com. 1882, 68) was founded on a specimen of this same species with an abnormal number of teeth.

18. Campostoma anomalum Ag.

19. Catostomus teres (Mitch.) Günth.

20. Ictiobus velifer (Raf.) J. \& M.

Characters essentially those of the specimens collected at Concordia.

21. Ictalurus punctatus (Raf.) Jor.

22. Amiurus melas (Raf.) J. \& Copel.

Common.

\section{VI.-Smoky Hill River, Wallace, Wallace County.}

The Smoky Hill River at Wallace is much like the Saline at Wa Keeney, but smaller and more rapid. At a point within two miles from the railroad station the stream has been dammed, in order to furnish a supply of water for the railroad tanks, to which it is forced through pipes. Above this dam, where the water is several feet deep, we secured the greater part of our collection. Nineteen species are enumerated. 
1. Etheostoma lepidum (Bd. \& Gd.).

Some of the males of this species were most brilliantly colored. The vertical bars of indigo-blue were separated by bands of orange, which was especially bright on the caudal peduncle. Much orange adorned the anterior part of the body above the lateral line. Both dorsals with a broarl band of orange or scarlet.

2. Lepomis humilis (Grd.) Cope.

3. Lepomis cyanellus Raf.

4. Fundulus zebrinus J. \& G.

This species is very abundant in the vicinity of Wallace, and very fine and large specimens were collected. Little is to be added to Dr. Gilbert's very full description given of this species in the Bulletin of the Washburn Laboratory, 1884, vol. i, p. 15. In my specimens the eye is contained in the length of the head 5 times. The base of the dorsal in the total length $7 \frac{1}{3}$ times in the female, and $5 \frac{1}{2}$ times in the male. In the males the anterior margin of the dorsal is midway between the tip of the snout and the tip of the caudal; in the females it is set considerably further back.

Length of the longest specimen, 4 inches.

6. Semotilus atromaculatus Mitchill.

6. Hybopsis biguttatus (Kirt.) J. \& M.

7. Phenacobius mirabilis (Grd.) Jor.

With 44 transverse rows of scales. Teeth 4-4, no traces of an inner tooth on either pharyngeal. A dorsal dusky streak and a dark band from the snout through the opercle to the caudal, where it terminates in a distinct black spot.

8. Notropis megaiops (Raf.) J. \& M.

9. Notropis deliciosus (Grd.) Jor. \& M'k.

Common. A row of dark specks along the lateral line. Scales above dark-edged. A vertebral dusky streak and a lateral silvery band. Snout dusky.

10. Notropis lutrensis (Bd. \& Gd.) Gilbert.

Abundant.

11. Notropis æneolus Hay.

Fins all brilliantly red. Whole head and eyes red, and body with a tinge of the same color.

12. Notropis germanus Hay, sp. nov.

It is with reluctance and trepidation that I add another specific name to the deliciosus group of Notropis. In my collection made at Wallace is a single specimen which I have not been able satisfactorily to refer to any described species. Were the intestinal canal not so short-shorter than the body-the specimen might be referred to Hybognathus (Dionda) nubila Forbes. Under the circumstances I deem it better to describe the form as new. 
The form of the fish is much like that of $N$. deliciosus, being, perhaps, somewhat slenderer. Head in length, 4 ; depth, 5. Head somewhat like that of deliciosus. Mouth like this species, but smaller, the maxillary not reaching back to a perpendicular from the front of the orbit. Head, viewed from the side, somewhat more pointed than that of deliciosus, the snout not being so heavy. The antorbital bone distinctly larger and projecting further toward the tip of the snout than that of deliciosus. Eye greater in diameter than the length of the snout; contained in the head $3 \frac{1}{3}$; the snout in the head $4 \frac{1}{2}$. Teeth 4-4, with distinct masticatory surface; the first tooth hooked.

D. I, $8 ; A$. I, 9, the ninth ray dividing at its base into two subordinate rays. Insertion of the dorsal directly over the ventrals. Pectorals falling short of the ventrals; the latter extending to the vent. Caudal peduncle longer and slenderer than in deliciosus.

Scales $5-35$ or $36-4 ; 15$ between the occiput and the first dorsal ray. The color is quite dark above, all the scales having broad dusky edges. The sides are silvery, but through the silvery band there runs from the snout to the caudal base a distinct dusky streak. This streak is very distinct on the snout and opercle. Along the sides the streak is rather leaden in hue, but the pores of the lateral line are distinctly marked by black dots. Top of the head dusky. Belly, lower jaw, and throat pale. Cheeks and opercle silvery. A narrow black line along the lower edge of the caudal peduncle.

Dorsal, caudal, anal, and front edge of the pectoral fins dusky, with black punctulations; the ventrals pale.

Total length of the specimen a little over $2 \frac{1}{2}$ inches.

13. Notropis lutrensis (Bd. \& Gd.) Gilbert.

Numerous specimens. Transverse rows of scales 34 in one specimen. Depth, $2 \frac{3}{4}$. Others slenderer.

14. Pimephales promelas confertus (Grd.) Gilbert.

15. Hybognathus nuchalis Ag.

16. Campostoma anomalum.

17. Catostomus teres.

Apparently abundant.

18. Amiurus melas.

19. Noturus flavus.

Indianapolis, Ind., August 7, 1886. 


\section{$2 \mathrm{BHL}$ Biodiversity Heritage Library}

Hay, Oliver Perry. 1887. "A contribution to the knowledge of the fishes of Kansas." Proceedings of the United States National Museum 10(624), 242-253. https://doi.org/10.5479/si.00963801.10-624.242.

View This Item Online: https://www.biodiversitylibrary.org/item/32314

DOI: https://doi.org/10.5479/si.00963801.10-624.242

Permalink: https://www.biodiversitylibrary.org/partpdf/23721

\section{Holding Institution}

Smithsonian Libraries

\section{Sponsored by}

Smithsonian

\section{Copyright \& Reuse}

Copyright Status: NOT_IN_COPYRIGHT

This document was created from content at the Biodiversity Heritage Library, the world's largest open access digital library for biodiversity literature and archives. Visit BHL at https://www.biodiversitylibrary.org. 